\title{
Reading Kant in the Light of Political Theology
}

Why read Kant in the light of political theology in a secular age? Answering this question is the key challenge to those who stress the importance of examining the theological roots of the political essays of Kant or any other icon of IR theory. Even if it is conceded that Kant's inspiration was theological or metaphysical in nature, argue those sceptical of the politicaltheological school, this is unimportant in the twenty first century context. If Kant is to remain relevant, the sceptics argue, the 'rational' core of Kant's project must be extracted from any metaphysical and theological baggage that surrounds it, only then may it be subsequently put to use in relation to contemporary theory and practice. The key question for such authors then is 'how do we relate Kant to our contemporary context and from the perspective of our theoretical projects?' To reintroduce elements of metaphysics and theology, so this line of thinking goes, would be irrelevant, or even an impediment, to the forward march of valuable ways of looking at the world such as cosmopolitanism or Democratic Peace theory. Such a recovery would be particularly unwelcome in the case of political theology, tainted as it is by association with its most infamous proponent, the Nazi Kronjurist, Carl Schmitt. ${ }^{i}$

In this chapter, I will offer three reasons why a political-theological reading of Kant is necessary. The first, and most important, reason is because Kant's texts rely upon theological ideas: Kant's constant invocation of providence, radical evil, God (in various roles), and the afterlife all require serious attention. These ideas are not inessential, they are vital components of Kant's system of thought. Removing these central elements from the complex series of intersecting and connecting ideas and concepts that compose the architectonic structure of Kant's thought has serious implications both for Kant's theorisation of the problems and his solutions to those problems. The second reason for reading Kant by reference to political theology is that such an approach offers a valuable interpretive key to understand Kant's work as a whole. One of the most intriguing aspects of Kant's work that I uncovered in Kant's International Relations (Molloy, 2017) is the extent to which his works interrelate: this is particularly the case in Toward Perpetual Peace, in which elements of Religion Within the Bounds of Mere Reason, the three Critiques, Idea for a Universal History, and several other works, are brought together in systematic fashion. The third reason a political-theological reading of Kant is valuable relates to those authors who would dismiss the importance of theological and metaphysical elements of his theorisation of global politics. To these authors, political theology poses a question of its own: you may wish to remove the load bearing metaphysical walls and theological foundations of Kant's system, but with what concepts and ideas of equivalent power do you propose to replace them? The components of Toward Perpetual Peace that attract contemporary theorists are intrinsically linked to those that repel them, to save the former, it is necessary to address the latter and propose adequate substitutes - a task cosmopolitan theorists have not been concerned to conduct. Without providing alternative foundations, the ideas contemporary cosmopolitan theorists pluck from his work are unmoored and fall prey to the contradictions that Kant resolves by reference to theology and metaphysics. Nobody, I would argue, needs to pay more attention to Kant's theological and metaphysical commitments than his contemporary adherents in the study of global politics, yet it is they who remain most unaware of the need to do so.

\section{Kant's International Relations Viewed Through the Political-Theological Prism}


Political theological themes permeate Kant's work, particularly those texts in which he develops (with all relevant provisos regarding the anachronism of the phrase) his theory of International Relations. As early as Idea for a Universal History with a Cosmopolitan Aim (1784), Kant invokes both the shortcomings of human beings (the philosopher 'cannot at all presuppose any rational aim of theirs ... in this nonsensical course of things human') yet also insists on the necessity of belief in 'the teleological doctrine of nature' - a doctrine of purposiveness in nature that is necessary because without it 'we no longer have a lawful nature but a purposelessly playing nature; and desolate chance takes the place of the guideline of reason' (2009 [1784], p. 11). Kant is quite clear that without this assumption (i.e., leap of faith) of purposiveness and belief in the ultimate salvation of mankind, the species would have to 'remove all practical principles' (ibid., p. 12). The continual improvements of mankind's natural abilities through the vicissitudes of nature (including unsocial sociability) 'betray' according to Kant 'the ordering of a wise creator' (ibid., p. 14). Rejecting chance, Kant insists upon nature being comprehended as a rational whole, and expresses this preference in explicitly theological terms, i.e., 'philosophy can also have its chiliasm; but one the bringing about of which is promoted by the very idea of it' (ibid., p. 19). The chiliastic idea of nature having a purpose and a determined end or telos (one may make no ontological claim regarding eventual salvation - the principle, for all its necessity, remains solely practical) may 'serve us as a guiding thread for exhibiting an otherwise planless aggregate of human actions, at least in the large, as a system' (ibid, p. 21). Kant's claim that this 'justification of nature or better, of providence,' (ibid., p. 22) is clearly both theological and political in that 'if that part of the great showplace of the highest wisdom that contains the end of all this - the history of humankind' (ibid.) is merely the product of purposeless chance, then human existence would be a reproach to the rational design of the universe and 'a ceaseless objection against it' (ibid). Mankind viewed from this angle 'necessitates turning our eyes away from it in disgust, and in despair of ever encountering a completed rational aim in it, to hope for the latter only in another world' (ibid.).

The Idea for a Universal History then introduces the key distinction that would shape Kant's political theology of IR: either we read nature as a senseless, hopeless, blind mechanism in which the aggregate of human beings lives out a miserable existence without purpose; or, we have faith that nature, ultimately, is purposive - that there is a plan to existence, which has mankind in its ideal form, humanity, as its telos. ${ }^{2}$ The theme of purposiveness is developed further in the Critique of the Power of Judgment. Kant introduces a distinction into the power of judgment between determining and reflective powers of judgment that allows the legitimate exploration of the idea of purposive nature in a manner that does not violate the limits of knowledge as laid out in the Critique of Pure Reason. In theological terms, those limits are made most clearly in the fourth antinomy of pure reason, in which Kant claims it is impossible to know whether or not God exists. It would therefore transgress the limits of knowledge to claim that God exists. The practical interest of reason, however, lies in accepting (in the absence of knowledge) the thesis that 'all order in the things constituting the world is due to a primordial being, from which everything derives its unity and purposive connection,' the alternative, that no such being has so ordered the universe, 'robs us' of the fundamental basis of morals and religion (Kant 2007 [1781/1787], p. 424). 'If there is no primordial being distinct from the world,' continues Kant, 'if the world is without beginning and therefore without an Author, if our will is not free, and the soul is divisible and perishable like matter, moral ideas and principles lose all validity' (ibid). The Critique includes an emphatic 
restatement of the importance of belief in God (despite no knowledge of his existence being possible): 'while for the merely speculative employment of reason the supreme being remains a mere ideal, it is yet an ideal without a flaw, a concept which completes and crowns the whole of human knowledge' (ibid, p. 531). ${ }^{3}$ The limits of knowledge are important precisely because they forced Kant (ibid, p. 29) to 'deny knowledge, in order to make room for faith.'

In a manner similar to the endorsement of the theses of the antinomies of pure reason, Kant argues in The Critique of the Power of Judgment that the assumption of purposiveness is justified for practical purposes, i.e., it provides a basis for the theorisation of rational moral existence by allowing the consideration of nature beyond the operation of mechanical forces. The assumption of purpose leads inevitably to the question of intent: if the universe is treated as if it is purposive, what might nature's purpose be? This assumption would be illegitimate within the faculty of understanding, but is permissible in the reflective power of judgment and is necessary as it sheds light on important matters relating to human life when viewed from outside the mechanism of nature. Kant's aim in stressing the legitimacy of purposiveness is that purposiveness entails meaning; purposelessness, conversely, implies that human existence is meaningless. It is important to stress that it is this fear of meaningless that impels Kant to argue the case for interpreting nature as if it is the product of an artist's hand, i.e., that it has been created for a purpose or with a particular end in mind. The only other plausible interpretations are unappealing: nature, and by extension mankind, is merely a meaningless product of chance factors coinciding, or God is a capricious entity who created the universe without any purpose. None of this is to claim that God exists, but rather that nature only has meaning if it is comprehended as if a God is its author. Nature, cognised as God's art, 'invites profound investigations into the possibility of such a form' (Kant 2000 [1790/1793], p. 140).

From the perspective of the political theology that reaches its culmination in Toward Perpetual Peace, the most significant of the 'profound investigations' that Kant undertakes in the Critique of the Power of Judgment is his representation of mankind's existence in teleological terms. Kant's teleology rests on belief that God ('an unproven but necessary postulate') is the author 'of both the sensible and the supersensible aspects of both the natural and the practical destinies of mankind' (Molloy 2017, p. 64). Mankind in its practical, moral guise is the only candidate qualified to serve as 'the final end' of nature, 'to which the whole of nature is teleologically subordinated' (Kant 2000 [1790/1793], p. 303). The teleological subordination of nature enables Kant to think about the potential resolution of human history from a point outside where human beings appear to be, i.e., mired in the mechanism of nature. Kant's alternative point of orientation within the reflective power of judgment allows a different kind of destiny: one in which the natural politics of prudence and self-interest is transcended by the reformation of international society in the image of moral and rational relations based on right and the moral law as developed in The Groundwork and The Critique of Practical Reason. Kant is concerned therefore with the transformation of nature, 'into something entirely different, namely into that which steps beyond nature,' but it can only do so by reference to that which is outside Nature, a frame of reference that is unavoidably metaphysical and, ultimately, theological (ibid., p. 192).

The Crooked Wood Problem: Radical Evil and the Insufficiency of Human Beings 
Kant's declaration of independence from the dominance of nature and its incentives faces one, exceptionally difficult, problem: the insufficiency of human beings as they appear to be to approximate the level of rational insight and moral character sufficient to effect the reorientation of the species in a manner even approximating his teleology - as Kant (2009 [1784], p. 16) famously writes in Idea for a Universal History: 'out of such crooked wood as the human being is made, nothing entirely straight can be fabricated.' ${ }^{4}$ Human beings are not merely natural entities, they are morally corrupt to the extent that Kant argues the species exhibits a universal tendency he refers to as 'radical evil.' Radical evil involves the 'innate guilt' (Kant, 1996a [1793], p. 84) - both unintentional (culpa) and intentional (dolus) - of human beings that is the result of an inherent tendency to act contrary to the moral law. This guilt, according to Kant (ibid.), is 'characterized by a certain perfidy on the part of the human heart (dolus malus) in deceiving itself as regards its own good or evil disposition.' The deception of the self is extended to others, leading to a species wide inability 'to judge what to think of a human being' that 'renders any imputability entirely uncertain' (ibid., p. 85). Radical evil fosters the thoroughgoing corruption of dishonesty that 'constitutes the foul stain of our species' according to Kant, and he is adamant that 'so long as we do not remove it, it hinders the germ of the good from developing as it otherwise would' (ibid). In an efficient metaphor, Kant (ibid., p. 113) elaborates that radical evil is 'the debt that precedes whatever good a human being may ever do.' The exacting nature of Kant's theology of sin viewed through the prism of rational morality is instructive: 'because the evil is in the disposition and the maxims in general (in the manner of universal principles as contrasted with individual transgressions): consequently, every human being has to expect infinite punishment and exclusion from the Kingdom of God' (ibid.). Kant's standard is clear: 'any person who does not always make the moral law their sole and supreme incentive for adopting a maxim has an evil disposition' (Formosa 2007, p. 235).

Despite the universal pervasiveness of radical evil in each and every huma $n$ being, Kant opens a path to salvation by which the foul stain of the species might be removed. The key to this salvation lies in recognizing the precise nature of the evil that afflicts human beings. Although the species is mired in evil, argues Kant, this evil is the lesser of two kinds. The human being 'is only evil because he reverses the moral order of his incentives in incorporating them into his maxims,' (Kant, 1996a [1793], p. 83) by which Kant means that human beings subordinate morality to self-love and inclinations to power, lust, etc. Human beings therefore are merely perverse as opposed to malicious.

Although they are evil because they fail to choose to act according to the dictates of rational morality, human beings have the capacity to reject evil and to follow the moral law. Central to Kant's insistence on the possibility of orienting human beings away from their perverse incentives to evil is a distinction he draws between predispositions and propensities. The corruption in human beings, introduced by what Kant (ibid., p. 121) calls 'the evil principle,' can be reversed through the recognition that the predisposition to the good is prior to, and more elemental, than that of the propensity to evil. ${ }^{5}$ The moral law allows the articulation of the principles of the good and thereby provides a template for the moral reformation of the species, effecting what Kant (ibid., p. 92) calls 'a revolution in the disposition of the human being.' The revolution in the disposition of the human being is a form of moral rebirth, with the redeemed entity qualitatively different from that which preceded it. 
Kant's vision for how this reorientation of the human being may be achieved incorporates both natural pressures and mankind's own efforts at improving its moral capabilities by means of education. Nature, through the operation of its mechanical forces, including human instincts and passions, forces human beings to adapt to all physical terrains. Unsocial sociability, the condition of being simultaneously attracted to other human beings, while also being compelled to compete with them for resources and esteem, also forces human beings into social arrangements that culminate in civilization. Civilization is itself a double-edged sword in that it both allows for the development of human talents and political and social organization, but also encourages the indulgence of $\sin$ in all its varieties. It is for this reason that Kant (ibid., p. 81) insists that 'vices of culture and civilization,' are 'the most offensive of all.' One product of civilization that offers hope to mankind regarding the possibility of salvation, however, is education.

Education is an example of the kind of 'rational contrivance' that Kant identifies as mankind's capacity to contribute towards its moral and social improvement (Munzel 2003, p. 54). Kant develops a theory of education that revolves around the ideal 'of a future possible improved human condition, in accordance with the idea of humanity and its entire destiny.' Kant's (2007b [1776/1777], p. 103) linkage of education to cosmopolitanism explains his enthusiastic support for Johan Bernhard Basedow's pedagogically innovative 'philanthropium' school, 'which is dedicated to humanity and therefore to the participation of every cosmopolitan.' Human insufficiency, however, works against the positive effect of education.

The problem of education, irresolvable in human terms, according to Kant, is that the education of human beings is provided by other human beings, 'who by virtue (or vice) of being human are consequently compromised in terms of providing an increase in edification' (Molloy 2017, p. 116). Education by higher beings might resolve this problem, but in their absence it is impossible to speculate as to the extent to which mankind might improve. Kant's resolution of this dilemma revolves around a possible future that allows for hope in the almost infinitesimally gradual improvement of human nature over time. ${ }^{6}$ Kant's (2007c, pp. $459-60,473$ ) preferred educational program is one that marries the study of rational morality and prudence. It seems to be designed to create the 'moral politician' of Toward Perpetual Peace, a figure who is both politically savvy, yet resolutely morally upright. There is, however, no escaping the fundamental paradox of human education: 'He who is to educate' the human being, is him or herself, 'a human being who still lies in the crudity of nature .... Hence the continuous deviation from his vocation with the always-repeated returns to it.' Kant (2007d [1798], pp. 420-41) resignedly admits that there can be no guarantee of progress due to education by humans, and that its capacity to contribute towards human improvement must remain only a hope, because there is 'no guarantee against regression.' Kant's solution to this problem is to offer belief in 'education from above' as a necessary supplement to human efforts to improve their moral condition by education. The provision of this 'education of the human race,' Kant explicitly states, can be expected by the human being 'only from Providence; that is, from a wisdom that is not his, but which is still (through his own fault) an impotent idea of his own reason' (ibid., p. 423). ${ }^{7}$ The education from above consists in the 'harsh and stern' cultivation of human nature and capacities, an education so severe and exacting on mankind that Kant asserts it 'extends through great hardship and almost to the 
extinction of the entire race' (ibid). God may be believed to have a plan for the rescue of mankind, but the process of salvation will not be easy.

The Necessity of Belief: God as Holy Lawgiver, Benevolent Ruler and Just Judge

Kant professes belief in God because without it, 'we have precisely no ground to suppose that the world dances to the tune of human needs' (Byrne 2007, p. 89). In the absence of belief in God and the afterlife, mankind's efforts at rational and moral reform are impotent gestures, 'painful and feeble striving toward an empty and meaningless goal' (Wood 1970, p. 178). Kant's God is required by the demands of rational morality to be perfect, omniscient and omnipotent in order to act as the inspector of the human heart and its intentions and to have the capacity to 'arrange the whole of nature to accord with the way I act regarding my morality' (Kant 1996b, p. 356). Such a God would also have to be 'holy and just; for otherwise I would have no hope that the fulfillment of my duties would be well-pleasing to it' (ibid.). Kant insists that as a consequence 'the existence of a wise governor of the world' as opposed to brute nature, 'is a necessary postulate of practical reason' (ibid.). The necessity of the postulate is made clear by Kant's conclusion that without it 'all subjectively necessary duties which I as a rational being am responsible for performing will lose their objective reality. Why should I make myself worthy of happiness through morality if there is no being who can give me this happiness?' (ibid., 407). If human beings are simply rational creatures, then by foregoing any advantage in favour of the chimera of an unmoored, unrewarded morality, they would be involved in a kind of practical irrationality unless they believe in the future life and a providential and gracious Deity' (Wood 1992, 403). Reason must combine with the fear of the vacuum of meaning that the absence of God entails in order to find a foundation for moral behaviour in faith. Once the practically necessary leap of faith is made, a clearer picture emerges of God's political-theological role. According to Kant (1996a, p. 165-66), practical reason requires that God be conceived as '(1) the almighty creator of heaven and earth, i.e., morally as holy lawgiver; (2) as the preserver of the human race, as its benevolent ruler and moral guardian; (3) as the administrator of his own holy laws, i.e., as just judge.'

\section{Toward Perpetual Peace I: Sin, Infernal Arts, and the Prospect of Apocalypse}

The significance of Toward Perpetual Peace lies in its capacity to tie together in a coherent fashion the various strands of Kant's political theology. In particular, Toward Perpetual Peace is a sequel of sorts to Religion within the Bounds of Mere Reason and The Critique of the Power of Judgment in that it seeks to confront the political effects of radical evil and resolve the problems associated with human society on a global level within a teleological framework. The scale of Kant's task in this essay is revealed by the perverseness of human nature and its corruption of religious practice, which is made clear by Kant in a plaintive footnote regarding the sacralization of victory in war. Kant (1996c, p. 328) condemns the common practice of celebrating military victory by offering thanksgiving to God as being in 'marked contrast with the moral idea of the father of human beings.' Kant proposes instead calling for divine forgiveness for 'the great sin of which the human race continues to be guilty, that of being unwilling to acquiesce in any lawful constitution in relation to other nations ... preferring instead to use the barbarous means of war' (ibid.). As in Kant's wider oeuvre the political theological task is to account for this persistence of sinfulness, to identify the political implications of this enduring condition, and to offer the prospect of salvation in the face of 
the apocalyptic resolution of human history Kant envisages as a potential consequence of human beings following the logic of war to its natural conclusion.

Kant's answer as to why human beings persist in the 'great sin' of refusing to institute a lawful form of politics among nations draws directly on the idea of radical evil developed in Religion Within the Bounds of Mere Reason. The use of war, Kant writes, is an 'inclination of those in power ... which seems to be implanted in human nature' (ibid., 319). The inherent 'malevolence of human nature' is seen 'unconcealed in the free relations of nations,' as, without civil laws and governmental constraint, radical evil proceeds unchecked (ibid., $p$. 326). The undisguisable and irrefutable malevolence of 'the external relations of states to one another' (ibid. p. 343) is, in fact, Kant's primaryargument in favour of the innateness of radical evil against the idea that it might be a symptom of localized cultural deficiencies within societies. Whereas the power of the state can constrain the evil of human beings in society, no such restraint exists at the international level, which allows malevolence free rein. Although each state considers itself moral in its relations with other states, it 'presupposes the evil disposition in all others,' with the result being that 'the judgment they mutually pronounce on one another is that they are all in fact of little worth' (ibid.). International society's absence of sovereign power encourages the 'self-seeking propensity of human beings,' ensures the continuing conflict between politics and morality, and fosters 'the deceitful and treacherous but yet subtly reasoning principle in ourselves which pretends that the weakness of human nature justifies any transgression' (ibid., p. 346).

A condition in which each state assumes the evil intentions of its neighbours, and as a consequence that any means are justified to protect that state from the machinations of others, produces a reliance on prudence and an eschewal of rational morality. Prudence provides an alternative 'theory of maxims for choosing the most suitable means to one's purposes aimed at advantage,' the acceptance of which is 'to deny that there is a [doctrine] of morals at all' (ibid., p. 338). The sole brake on the conduct of states (who pay only lip service to right) operating according to the doctrine of prudence is their calculation of the political and economic consequences of their actions. In such an environment the use of both force and fraud are permissible due to the absence of trust in the goodwill of other states. The danger posed by the erosion of trust is raised by Kant in the sixth preliminary article wherein 'acts of hostility' that 'make mutual trust impossible,' are identified as 'infernal arts' that perpetuate war between states. Such is the danger of such practices that if they are employed on a regular basis, 'they would also be carried over into a condition of peace, so that its purpose would be altogether destroyed' (ibid., p. 320). The calamitous effects of the untrammeled use of the doctrine of prudence is most evident in relation to the East Indies (Hindustan),' in which the 'civilized, especially commercial' states of Europe 'brought in foreign soldiers' (force) 'under the pretext of merely proposing to set up trading posts' (fraud), which resulted in 'the oppression of the inhabitants, incitement of the various Indian states to widespread wars, famine, rebellions, treachery, and the whole litany of troubles that oppress the human race' (ibid., p. 329).

The ominous danger of the infernal arts lies in the prospective universalization of their effects, with the world becoming colonial India in macrocosm. The preliminary articles in particular are concerned with uses of technical practical reason that extend the range of the doctrine of prudence ever further. Dynastic marriage (preliminary art. 2 ) is identified as a dangerous 
means of extending territory and predominance, with the conjoined states not only depriving states of their moral personality and their populations of established rights, but also threatening neighbouring enemy states by hiring soldiers (reduced to the status of things also raised in prelim. art. 3) to the other party in the marriage. The establishment of standing armies is a further problem in that they 'spur states on to outdo one another in the number of armed men,' a phenomenon, which, according to Kant (ibid., p. 318), 'knows no limit' (emphasis added). The most threatening practice, however, is the use of debt to finance wars. This innovation, 'the ingenious invention of a commercial people in this century' (ibid., p. 319) is a 'dangerous power of money,' that extends the capacity to wage war beyond what had previously been possible in that it enabled that state to develop 'a treasury for carrying on war that exceeds the treasuries of all other states taken together ... [combined with] a facility in making war ... which seems to be implanted in human nature, is therefore a great hindrance to perpetual peace' (p. 319). The practice of seeking credit for the waging of war must cease because quite apart from the immediate destruction of the war, the 'finally unavoidable' bankruptcy of the debtor state 'must entangle other states in the loss without their having deserved it.' Creditor states are justified, according to Kant, 'in allying themselves against such a state and its pretensions,' (ibid.) with the result being that the introduction of credit financing wars will inevitably extend its destructive capacity far beyond the conflicting parties and poison peace on an extensive scale.

Kant extrapolates an all too possible apocalyptic denouement to human history from the extension and intensification of war's capacity to affect the species. War undergoes a qualitative change when taken to the extreme means that the sixth preliminary article proposes to outlaw. War's role had been to act as a 'regrettable expedient for asserting one's right by force in a state of nature (where there is no court that could judge with rightful force).' In a situation characterized by the extreme doctrine of prudence, in which trust 'in the enemy's way of thinking' is erased by the use of 'dishonourable stratagems,' a new, much more terrible form of war, war of extermination, replaces war waged for the assertion of a state's right in relation to others. War of extermination, in a system in which all states are increasingly interconnected politically and financially, poses the ultimate threat to mankind's existence as it potentially involves 'the simultaneous annihilation of both parties and with it of all right,' culminating in the apocalyptically ironic 'perpetual peace come about only in the vast graveyard of the human race' (ibid., p. 320). The Grotian concept of there even being a right of nations to go to war is also implicated as contributing to this apocalyptic scenario. The Grotian concept of a right to war is 'unintelligible,' according to Kant (ibid., p. 328), because 'one would have to mean by it that it is quite right if human beings so disposed destroy one another and thus find perpetual peace in the vast grave that covers all the horrors of violence along with their authors' (ibid.).

\section{Toward Perpetual Peace II: Apocatastasis and Soteriology}

Unless nature (or that which must be believed to lie behind nature, providence) is as perverse as the human beings whose actions threaten their continued existence, it is reasonable to assume that the purposiveness that Kant insists 'shines forth visibly' from its 'mechanical course' is not the total erasure of the species. Whether a purely natural fate, or providential destiny, awaits mankind, war's transformation into that which threatens both fate and destiny forces serious consideration of what is at stake in this change in the character of war. 
At first confining his analysis of nature to the theoretical level (i.e., within the permissible limits of knowledge of things as they appear to be as identified in the Critique of Pure Reason) Kant infers from its supposed purposiveness three foundational presuppositions about nature: 'that it 1) has taken care that people should be able to live in all regions of the earth; 2 ) by war it has driven them everywhere, even into the most inhospitable regions, in order to populate these; 3 ) by war it has compelled them to enter into more or less lawful relations' (ibid., pp. 332-333). War, Kant hypothesizes, could only be waged following the development of agriculture practicing states, in which the domestication of the horse - 'the first instrument of war' - could be achieved. In parallel to the practice of war, human societies also developed trade networks based on commodities such as salt and iron, the trade of which brought these societies 'into a peaceable relation to each other and so into understanding, community, and peaceable relations with one another, even the most distant' (ibid., p. 333). Despite the existence of a peaceful alternative to war as a means of socialization of human communities in trade and cooperation, Kant insists that nature enforced its despotic will that mankind should live everywhere by choosing 'war to achieve this end' (ibid., p. 334).

War, which 'seems to be engrafted onto human nature' needs no special motive, but rather seems inherent in the species. War's perceived nobility impels human beings, driven by desire for honour, to place great store in military courage. Such is the esteem in which courage is held that 'war is often begun merely in order to display courage ... an inner dignity is put in war itself.' Even some philosophers have eulogized war 'as a certain ennoblement of humanity' (ibid., p. 334). ${ }^{8}$ Kant's own position is similar to that of 'a certain Greek, "War is bad in that it makes more evil people than it takes away."' Kant's ambivalence towards nature is revealed by his dismissive conclusion on its effects: 'So much for what nature does for its own end with respect to the human race as a class of animals' (ibid., p. 334). This passage is important in that it demonstrates that in purely natural terms the human race is merely an aggregate of animals, and that as nature continues to employ the means of war in order to direct human relations, it will produce ever greater numbers of evil people relative to good. By extension, as evil people proliferate, the more likely they are to use the doctrine of prudence at its most extreme.

Despite the proliferation of evil, Kant's theoretical reading of nature leads him to the conclusion that the ultimate effect of nature's purpose is to favour the development of conditions conducive to the humanity's moral purpose and the fostering of 'all three relations of public right: the right of a state, the right of nations and cosmopolitan right' (ibid.). War plays an important role in the development of an emergent international and cosmopolitan order as '[e]ven if a people were not forced by internal discord to submit to the constraint of public laws, war would still force them from without to do so,' as the pressure on their borders would force each people to 'form itself internally into a state in order to be armed as a power against' its neighbours. Nature even assists in the development of the most rightful of states, the republican form (complementing reason 'revered but impotent in practice') as nature's 'self-seeking inclinations' force technical practical reason to develop 'good organization of a state' by 'arranging those forces of nature in opposition to one another in such a way that one checks the destructive effect of the other or cancels it,' with the ultimate effect being that 'the human being is constrained to become a good citizen even if not a morally good human being' (ibid., p. 335). ${ }^{9}$ At the international level, states' rights are guaranteed by nature's separation of states, a separation that preserves rights against the threat of the 
'soulless despotism' of universal monarchy to which states aspire, but nature works against through the opposition of forces held by states. Nature uses language and religious differences, 'which do bring with them the propensity to mutual hatred and pretexts for war,' but - somewhat optimistically, and against the grain of his argument - Kant maintains that 'increasing culture and the gradual approach of human beings to greater agreement in principles, leads to an understanding in a peace that is produced and secured, not as in such a despotism (in the graveyard of freedom), by means of a weakening of all forces, but by means of their equilibrium in liveliest competition' (ibid., p. 336). Similarly, at the level of cosmopolitan right, self-interest protects individuals in their dealings with states as 'the spirit of commerce, which cannot coexist with war' through the 'power of money' compels states 'to promote honourable peace' through mediation, 'as if they were in a permanent league for this purpose' (p. 336-337).

Although nature guarantees and promotes peace, it is not peace itself. The condition produced by nature's operation is at best preparatory for peace. The problem with a natural order based in the equilibrium of states in liveliest competition is that it is rationally imperfect (in terms of pure practical reason) and, at best, indifferent to morality. The natural order is contingent upon perfect calculation of interests by all actors, such that these actors can restrain their passions ('mutual hatred', etc.) and cooperate effectively, e.g., to prevent the rise of one of their number to universal monarchy. This order is also prone to Mendelssohnian reversal: at any time its operation might cease to work optimally, and one decisive miscalculation could set the fall of the system in motion. ${ }^{10}$ Nature can only deliver an incomplete, contingent, temporary and uneasy form of peace consistent only with itself and the capacity of technical practical reason's capacity to manipulate nature's system and others within it - which in itself is not compatible with Kant's moral commandment that people should not be used as a means to an end, but rather as ends in themselves. Most importantly, the natural order is constantly threatened by states, stoked by religious and/or cultural hatred, following ever more extreme versions of the doctrine of prudence. Decisive innovations within that doctrine, such as dynastic marriage and the power of credit, threaten to overthrow the equilibrium upon which the natural order depends for its existence. As Kant admits, understanding the machinations of nature is 'not adequate for predicting its future' in theoretical terms. It is only in practical (i.e., moral) terms that nature's guarantee is sufficient to enable mankind to fulfil its 'duty to work toward this (not merelychimerical) end' of perpetual peace.

\section{Salvation by Faith: Belief in Providence as the Necessary Condition for Perpetual Peace}

At the core of Kant's analysis in Toward Perpetual Peace is the antinomy of the purpose he perceives at work in creation. Simple nature, as examined above, allows for the theorization of how it is possible for 'concord to arise by means of the discord between human beings even against their will' (Kant 1996c, p. 331). Kant does not restrict his analysis of purposiveness to this 'preparatory arrangement' of nature - Kant views this process apocatastatically, i.e., in terms of the eventual redemption of nature in general as well as mankind in particular (ibid., p. 332). ${ }^{11}$ The redemption of nature can only be achieved by belief in something beyond what nature indicates of its own character. In opposition to nature's inscrutable ends and mankind's indeterminable fate within its mechanism, Kant offers providence's insights into purposiveness when viewed as the intention of the profound 
wisdom of a higher cause directed to the objective final end of the human race and predetermining this course of the world' (ibid., p. 331). Providence as an idea has to be handled very carefully, as, in Kant's words, 'we do not, strictly speaking, cognize in these artifices of nature or even so much as infer [the existence of providence] from them but instead ... only can and must add it in thought,' (ibid., p. 332) in order to gain access to the objective final end of the human race as prescribed by pure practical reason. Nature is appropriate to describe the purposiveness of existence within the limits of knowledge gained by human experience. Kant stresses, however, that no one can make a theoretical claim about God's intention regarding nature's purposiveness (a misuse of reason by which 'one presumptuously puts on the wings of Icarus'). While to think in such terms is to go beyond the limits of knowledge in theoretical terms, in practical (i.e., moral and rational) terms it is dogmatic and well founded as to its reality' (ibid.). The key issue is one of comprehensibility and intelligibility of purposiveness, as not only is the providential reading of purposiveness permitted, according to Kant, the purposiveness of 'the mechanism of nature, to which the human being (as a sensible being) belongs,' can be made 'comprehensible to ourselves only if we ascribe it to the end of a creator of the world determining it in advance,' i.e., as a providential design (ibid., p. 331).

Kant's version of providence (ibid., p. 332) rejects divine intervention or collaboration 'toward an effect in the sensible' world. Kant proposes instead belief in a predetermining providence 'from a morally practical point of view (which is thus directed entirely to the supersensible)' wherein it may be believed that 'God, by means incomprehensible to us, will make up for the lack of our own righteousness if only our disposition is genuine.' In such a context 'the concept of a divine concursus is quite appropriate and even necessary' (ibid.). Kant's particular form of apophatic theology (MacKinnon 1974, p. 57; Cupitt 1982; Molloy 2017, p. 147), in which it is impossible to know if God exists, but in which it is possible to discern what the divine will would be in relation to what the moral law, enables the formulation of a resolution to the central conundrum of human existence: how best to resolve the tension between morality and politics? Taking Matthew 10:16 as his cue, Kant argues that the wisdom of serpents and the guilelessness of doves, have to be considered in relation to whether or not both qualities can be conjoined. If they cannot, then the tension between them cannot be resolved and mankind will remain poised between apocalypse and salvation. If they can be combined, however, 'then the concept of opposition is absurd, and the question of how that conflict is to be resolved cannot even be posed as a problem' (Kant 1996c, p. 339). Kant's solution to how the two qualities might be reconciled revolves around the capacity of rational-moral principles to overcome the limitations of power and its incapacity to predict the consequences of its own operation:

\footnotetext{
'The tutelary god of morals does not yield to Jupiter (the god of power); for Jupiter is still subject to fate, that is, reason is not sufficiently enlightened to survey the series of predetermining causes that would allow it to predict confidently the happy or unhappy results of human actions in accordance with the mechanism of nature ... But it throws enough light everywhere for us to see what we have to do in order to remain on the path of duty (in accordance with rules of wisdom), and thereby do toward the final end' (ibid.).
}

Against the 'despairing denial' of the 'practical man' who rejects his argument of the superiority of morals over politics on the basis that the human being 'is never going to will what is required in order to realize that end leading toward perpetual peace' (ibid., p. 340), 
Kant argues that the collective will of 'the whole of civil society' will coalesce around the principle of there being a 'rightful condition' of power in the service of public right. The actual exercise of this system might be imperfect, but if 'one finds it indispensably necessary to join the concept of right with politics, and even to raise it to the limiting condition of politics, it must be granted that the two can be united'(ibid.). ${ }^{12}$ The only way in which this conjunction would be possible, however, is in the person of the moral politician, 'who takes the principles of political prudence in such a way that they can coexist with morals,' as opposed to the political moralist, 'who frames a morals to suit the statesman's advantage' (ibid.). Kant accepts that the politics he professes requires 'a higher standpoint of anthropological observation,' but stresses that only by taking this perspective can the species become 'equipped [to] ... approach the right of a state and the right of nations, as reason prescribes' (ibid., p. 341). The alternative is to persist with the chicanery of the moralizing politician, the despotism of an unredeemed nature, and the eventual likelihood of extermination. In the contest between an ends based political morality and a moral politics based on the formal principle of the categorical imperative - 'So act that you can will that your maxim should become a universal law' (ibid., p. 344) - the latter is clearly the better option because 'as a principle of right, it has unconditional necessity, whereas the former necessitates only if the empirical conditions of the proposed end, namely of its being realized, are presupposed' (ibid.).

The persistent failure of attempts to subordinate morality to politics constitutes the harsh education from above to which Kant refers elsewhere. As each warring party transgresses against his equally ill-willed opponent, as well as the 'concept of right, which alone could found peace in perpetuity,' their mutual destruction represents a lesson from which 'posterity may some day take a warning example' (ibid., p. 346). The warning constituted by the persistent failure (and increasingly apocalyptic threat) of the doctrine of prudence and the promise offered by the rational moral principles embodied in the formula of the universal law, lead Kant to the conclusion that 'Providence is thus justified in the course of the world; for the moral principle in the human being never dies out, and reason, which is capable pragmatically of carrying out rightful ideas in accordance with that principle, grows steadily with advancing culture' (ibid., p. 346). Belief in providence, the idea that God has arranged the world for the ultimate benefit of the human species, is revealed therefore as the element that is necessary for the completion of the process of perpetual peace that is guaranteed by nature. It is only through this belief that the apocatastatic task of redeeming nature, and human beings, can be achieved.

\section{Kant Contra 'Kantianism': The Genealogical Effect of Political Theology.}

In disciplinary terms, the advantage of reading Kant in terms of his political theology is the greater interpretive depth it allows regarding Toward Perpetual Peace's place in the wider system of Kantian thought, and the importance of that system to the understanding of this crucial text. In this light, it becomes clear that Toward Perpetual Peace is part of a wider anthropodicy that revolves around Kant's eventual 'master question,' i.e., 'What is Man?' (Kant 1992 [1800], p. 558). Kant's answer to this question in Toward Perpetual Peace i.e., that mankind can be understood from higher and (by implication) lower anthropological vantage points is the key move in his attempts to confront and overcome the problem of politics, culminating in the ultimate resolution of human history in Toward Perpetual Peace's 
convergence of nature with belief in providence. Kant's philosophical anthropology in effect argues that mankind (when viewed as the aggregate of human beings) is both part of, and constrained to act within, nature. The condition of human beings is further complicated by radical evil's capacity to amplify the worst tendencies of self-regarding natural entities. Kant is emphatic in recognizing both the extent of this problem and the tenuous, uncertain nature of the route he offers by which rational morality and faith in providence can plot a course from how things "are" (or more accurately, appear to be) and how things ought to be (according to pure practical reason). Kant's (1996c, p.346) theorization of this process is very much informed by his commitment to the principle that it is only on the assumption that mankind can be redeemed that it has any value.' Kant's soteriology is, in turn, rooted explicitly in a form of practical faith.

No such faith informs the projects of Kant's contemporary cosmopolitan acolytes - except perhaps in the sense that an unexamined and uncritical faith in human reason (when contrasted with Kant's philosophical anthropology) prevails within this discourse. The most prominent of the cosmopolitans who invoke Kant, e.g., Thomas Pogge (2008) and David Held (2010), offer political theoretical positions of undoubted sincerity, but fail to pass the Hume (2007 [1740], p.302) test regarding the shift from 'is' to 'ought' in their moral discourse. ${ }^{13}$ Hume's observation that moral theories exhibit a significant problem when they shift without acknowledgment from propositions based on how things are to how they ought to be is dealt with by Kant by his re-designation of mankind as in itself a 'transcendental object' and by extension of its ineffability as a thing in itself. Kant then proceeds to demonstrate how, when perceived as merely 'viewpoints' that are products of an anthropological perspective, what appears to be can be altered through reorientation toward what ought to be. This process, however, is dependent on a series of very particular metaphysical and theological commitments developed or reconfigured through the critical philosophy. Ought may imply can for Kant, but he recognizes that what mankind can do depends on a framework in which what can be becomes possible.

By contrast, contemporary 'Kantian' cosmopolitans do not have recourse to this process due to their refusal of Kantian metaphysics. In their determination to derive a set of moral and legal instruments from Kant's texts to employ in their efforts to argue the case for global cosmopolitan reform, theorists such as Pogge reject or ignore those elements of Kant's project that entail political, metaphysical, or theological commitments they do not recognize as useful or compatible in relation to their own projects. Pogge's cosmopolitan programme of gradual reform and evolution of the international political system away from the dominance of states to a more variegated, multi-layered format in which states form only part of a more complex whole, and are subject to disciplining effects from above, below, and the side, if they violate cosmopolitan norms, is an intriguing proposition but is not, properly speaking, compatible with Kant's position as it does not profess a fully worked out philosophical anthropology that addresses the ultimate cause of war and injustice, i.e., the moral and rational insufficiency of human beings. As I argue in Kant's International Relations (Molloy, 2017, pp. 168-169) an evolution of international society into more diverse forms will not in itself solve the problems of international relations and runs the risk, if the mediaeval political system is any guide, of actually making the situation considerably worse. The problem is not the political system per se, the problem is the character of those who make the system in the first place - politics is predicated upon self-preservation and exploitation of others as 
a symptom of what is at root a problem of mentality and orientation. As long as human beings remain in thrall to technical practical reason their orientation will continue to reflect the lessons of prudence, which is the fruit of human knowledge of the self and others.

At root, the Kantian cosmopolitans have forgotten or have chosen to ignore that 'what is man?' is Kant's ultimate question, one which cannot be fully answered without recourse to metaphysics and theology. Pogge's plans founder on this rock: he can articulate solutions to world political problems, but he cannot address the major flaw in his analysis: why would those responsible for, and indifferent to, the serial injustices he identifies in world politics, who possess massive structural advantages of wealth and power they are not reluctant to deploy at any and every opportunity, enact the schemes that Pogge requires of them? Pogge can articulate a moral project of reform, but he cannot bridge the gap between 'is' and 'ought' - the contemporary 'Kantian' cosmopolitan is a voice crying in a godless and faithless wilderness, issuing commandments to a largely indifferent world with little prospect of that world being compelled by the power of his/her argument to change its ways. What the cosmopolitan knows of human beings is at odds with his/her moral evangel, and there is little hope that $s /$ he can articulate a means by which this gap can be bridged. As Michael Sandel (1982, p. 46) asks of Pogge's mentor, John Rawls: are 'Kant's metaphysics ... detachable 'surroundings' or inescapable presuppositions of the moral and political aspirations Kant and Rawls share - in short, whether Rawls can have liberal politics without metaphysical embarrassment'? ${ }^{14}$

The genealogical significance of my work on Kant is that it asks of Kant's latter day followers two tasks: a) to become aware of the problem posed by their failure to develop an equivalent to Kant's philosophical anthropology, i.e., to explain why self-interested, finite and faithless human beings should institute any scheme of cosmopolitan reform? and b) to develop solutions to the is/ought problem that employ concepts and ideas of at least equivalent structural power to those of Kant's metaphysical and theological foundations and buttresses. Otherwise, the temple of 'Kantian' cosmopolitan rests on shifting sands and may collapse under the unsecured weight of what is dogma more than critique.

\section{Conclusion - 'What May I Believe?'}

My purpose in this chapter and in Kant's International Relations may be understood as a project of recovery. The target of this recovery is the critical ethos pioneered by Kant. Kant understood that his project was double-sided, poised between dogmatism and skepticism. Kant was aware that he could only make his system work by exploring in a circumspect and careful manner the ambivalent answers that can be carved out in an antinomian no man's land. Prompted by Hume to confront the limits of human knowledge, fear of what skepticism implied for existence forced Kant to 'deny knowledge in order to make room for faith' (2007a [1781/1788], p. 29). This ethos has in effect been jettisoned by contemporary Kantian cosmopolitanism in favour of dogmatic assertions of moral reform of international relations in contradiction of what Pogge and others recognize are the political conditions that prevail in the global political system. In this respect their program marks a step backwards toward the rational dogmatism opposed by Hume and Kant alike. Pogge's contradictions are not Kant's antinomies, and cosmopolitanism needs to reacquaint itself with the difference between the two if it is to evolve beyond them in the future. 
Kant's antinomies ultimately resolve themselves not by reference to knowledge but to practical faith. Much of Kant's anthropodicy revolves around the fifth question that Kant did not ask, but which is implicit from the Critique of Pure Reason onwards, i.e., 'What may I believe?' It is no coincidence that Kant (1996a [1793], p. 214) ties 'the idea of a cosmopolitan moral community' to the sacrament of communion (stripped of ecumenical and priestly accoutrements) as 'a good means of enlivening a community to the moral disposition of brotherly love which it represents.' It is also not a coincidence that Kant's projection of perpetual peace runs parallel to his project of the rationalizing of religion. As states and peoples discover and refine international and cosmopolitan political principles under the aegis of providence, Kant (ibid., p. 146) anticipates a contemporaneous process whereby the one true rational and practical religion eclipses the ecclesiastical faiths 'with the prospect at the end of flowering into the unchanging and all-unifying church triumphant!' In a lesson that needs to be considered in terms of the ramifications for cosmopolitanism in particular and IR theory in general, it is in the union of faith and reason that Kant (2007a [1781/1788], p. 635) finds an answer to the question that combines both practical and theoretical interests of reason, i.e., 'What may I hope?' If contemporary, secular Kantian theorists are to restore the foundations of hope, they will have to address the issue of replacing faith with a substitute capable of playing the role to which Kant apportions to it within the system of the critical and practical philosophies.

\section{Endnotes}

\footnotetext{
' Howard Williams $(2018,691)$ for example considers my juxtaposition of Kant and Schmitt in Kant's International Relations as 'irresponsible' and 'belittling' toward the former. Williams conflates all political theology with Schmitt's 'framework.' My interpretation of Kant deliberately contrasts Kant's political theology of the legislator against Schmitt's political theology of sovereign power and decision. Conversely, in his thorough review, Andreas Behnke (2018) writes 'one might wish that Molloy's reading of Carl Schmitt was as close and careful as his reading of Kant.'

2 On the distinction between how the transcendental object 'mankind' may be cognised as both natural human beings and as the rational and moral species humanity, see Molloy (2017, ch. 1).

3 In the Canon of Pure Reason, Kant writes: 'God and a future life are two postulates which, according to the principles of pure reason, are inseparable from the obligation which that same reason imposes upon us' (Kant, 2007 [1781/1787], p. 639).

${ }^{4}$ Kant was fond enough of this metaphor to deploy it twice, repeating it in Religion Within the Bounds of Mere Reason as, 'how could one expect to construct something completely straight from such crooked wood?' (1996a [1793], p. 135).

${ }^{5}$ The Evil Principle is Kant's equivalent to the figure of Satan in Christianity, also referred to fairly frequently by Kant as the Prince of this World.

${ }^{6}$ 'If some day a being of a higher kind were to look after our education, then one would see what the human being could become' Immanuel Kant (2007c, p. 439).

7 On Providence's relationship to mankind, Kant (2007d, pp. 423-424) writes: 'Providence signifies precisely the same wisdom that we observe with admiration in the preservation of a species of organized natural beings, constantly working toward its destruction and yet always being protected, without therefore assuming a higher principle in such provisions than we assume to be in use already in the preservation of plants and animals.'

${ }^{8}$ Kant himself endorses war over a degenerate peace: 'war, if it is conducted with order and reverence for the rights of civilians, has something sublime about it, and at the same time makes the mentality of the people who conduct it in this way all the more sublime, the more dangers it has been exposed to and before which it has been able to assert its courage; whereas a long peace causes the spirit of mere commerce to predominate, along with base selfishness, cowardice and weakness, and usually debases the mentality of the populace,' (Kant, 2000
} 
[1790/1793].P. 146). For a more developed discussion of Kant and war in the context of the sublime, see Behnke (2012, p. 261).

${ }^{9}$ Such is the power of technical practical reason according to Kant (1996c, p. 335) that it can even constrain 'a nation of devils (if only they have understanding).'

10 Kant (1996d) writes against Mendelssohn's cyclical interpretation of human history in the third section of On the Common Saying subtitled, 'On the Relation of Theory to Practice in the Right of Nations Considered from a Universally Philanthropic, that is, Cosmopolitan Point of View,' pp. 304-309. See also my interpretation (2017, pp. 78-82) of the significance of this philosophical disagreement to the development of Kant's position.

${ }^{11}$ For a discussion of apocatastasis in Kant see Molloy (2017, pp. 150-151) and Taubes (2009 pp. 73, 74, 128).

12 Kant is willing to entertain the opposite position, i.e., 'if there were no freedom and no moral law based upon it and everything that happens or can happen is instead the mere mechanism of nature, then politics (as the art of making use of this mechanism for governing human beings) would be the whole of practical wisdom, and the concept of right would be an empty thought' (ibid., p. 340) but the practical implications of this interpretation are sufficient for him to favour the providential alternative.

13 Lack of space forbids a detailed engagement with contemporary Kantian cosmopolitanism. The thumbnail sketch provided here is necessarily brief, but hopefully conveys in a succinct manner the precise nature of the problem.

${ }^{14}$ Cosmopolitans like Andrew Linklater, whose engagement with Kant is more tentative, face the same problem as Pogge, i.e., why should members of a species characterised by an anthropological tendency to intergroup conflict (Linklater: 2007, p. 3) - without any incentives other than moral suasion - decide to a) develop obligations towards humanity; b) privilege the intersocietal and humanity as a whole over their own interests; c) widen the circle of community (2007, p. 44)? Why would those who benefit from the inequalities of the status quo be motivated to alter the conditions of world politics to lessen the suffering of others? Linklater draws upon Norbert Elias to argue the case for society becoming less violent over time, but as Linklater admits $(2007$, p. 169) Elias himself argues that at the international level 'we are basically still living exactly as our forefathers did in the period of their so-called "barbarism."' Elias also stresses that decivilizing forces accompany civilizing forces in society - there is no guarantee that civilising forces will prevail or be reversed. Without a convincing foundation in something other than their own self-referential ideology, Linklater's unmoored Cosmopolitan principles are weightless moral preferences when measured against the material and social benefits possessed by privileged actors within international society. These weightless moral preferences are suggestive at best and not - as cosmopolitans like Linklater assert - legislative in relation to how the haves relate politically and economically to the have nots. By narrowing the range of options to cosmopolitan salvation or anarchic destruction, Nick Vaughn-Williams (2005, p. 174) argues that Linklater's legacy is one of '[e]thical fright and political paralysis.'

\section{References}

Behnke, Andreas. (2018). 'Book Review: Kant's International Relations,' H-Diplo. https://www.hnet.org/reviews/showpdf.php?id=52602

Behnke, Andreas. (2012). Eternal peace, perpetual war? A critical investigation into Kant's conceptualisations of war. Journal of International Relations and Development, 15 (2), 250-271.

Byrne, Peter. (2007). Kant on God. Farnham: Ashgate.

Formosa, Paul. (2007). Kant on the Radical Evil of Human Nature. Philosophical Forum, 38 (3), 221-245.

Held, David. (2010). Cosmopolitanism: Ideals and Realities. Cambridge: Polity.

Hume, David. (2007 [1740]). A Treatise of Human Nature: Being an Attempt to Introduce the Experimental Method of Reasoning Into Moral Subjects. Edited by David Fate Norton and Mary J. Norton. Oxford: Oxford University Press.

Kant, Immanuel. (2009 [1784]). Idea for a Universal History with a Cosmopolitan Aim. In Amélie Oksenberg Rorty and James Schmidt (Eds.), Kant's Idea for a Universal History with a Cosmopolitan Aim: A Critical Guide (pp. 923).Cambridge: Cambridge University Press. 
Kant, Immanuel. (2007a [1781/1788]). Critique of Pure Reason. Translated by Norman Kemp Smith. 2nd ed. Houndmills: Palgrave Macmillan.

Kant, Immanuel. (2007b [1776/1777]). Essays regarding the Philanthropinum. In R. Louden and G. Zöller (Eds.), Anthropology, History and Education (pp. 98-104). Cambridge: Cambridge University Press.

Kant, Immanuel. (2007c). Lectures on Pedagogy. In R. Louden and G. Zöller (Eds.), Anthropology, History and Education (pp. 434-85). Cambridge: Cambridge University Press.

Kant, Immanuel. (2007d [1798]). Anthropology from a Pragmatic Point of View. In R. Louden and G. Zöller (Eds.), Anthropology, History and Education (pp. 227-429). Cambridge: Cambridge University Press.

Kant, Immanuel. Critique of the Power of Judgment. (2000 [1790/1793]). Edited by Paul Guyer, translated by Paul Guyer and Eric Matthew. Cambridge: Cambridge University Press.

Kant, Immanuel. (1996a [1793]). Religion Within the Boundaries of Mere Reason. In Allen W . Wood \& George Di Giovanni (Eds.), Religion and Rational Theology (pp. 39-216). Cambridge: Cambridge University Press.

Kant, Immanuel. (1996b). Lectures on the Philosophical Doctrine of Religion. In Religion and Rational Theology, Allen W. Wood and George Di Giovanni (eds. Cambridge: Cambridge University Press.

Kant, Immanuel. (1996c). Toward Perpetual Peace. In Mary Gregor (Ed.), Practical Philosophy (pp. 317-351). Cambridge: Cambridge University Press.

Kant, Immanuel. (1996d). On the Common Saying: That May Be Correct in Theory, but It Is of No Use in Practice.' In Mary Gregor (Ed.), Practical Philosophy (pp. 277-309). Cambridge: Cambridge University Press.

Linklater, Andrew. (2007). Critical Theory and World Politics: Citizenship, Sovereignty and Humanity. Abingdon: Routledge.

Molloy, Seán. (2017). Kant's International Relations: The Political Theology of Perpetual Peace. Ann Arbor, University of Michigan Press.

Munzel, G. Felicitas. (2003). Kant on Moral Education, or 'Enlightenment' and the Liberal Arts. Review of Metaphysics, 57 (1), 43-73.

Pogge, Thomas W. (2008). World Poverty and Human Rights: Cosmopolitan Responsibilities and Reform. Cambridge: Polity.

Sandel, Michael J. (1982). Liberalism and the Limits of Justice. Cambridge: Cambridge University Press.

Taubes, Jacob. (2009). Occidental Eschatology. Translated by David Ratmoko. Stanford: Stanford University Press.

Vaughn-Williams, Nick. (2005). Protesting Against Citizenship. Citizenship Studies, 9 (2), 167-179.

Williams, Howard. (2002). Book Review: Kant's International Relations. Kantian Review, 23, 4, 689-693.

Wood, Allen. (1970). Kant's Moral Religion. Ithaca: Cornell University Press.

Wood, Allen. (1992). 'Rational Theology, Moral Faith, and Religion. In P. Guyer (ed.), The Cambridge Companion to Kant (pp. 394-416). Cambridge: CUP. 